\title{
Assessment of Hematobiochemical Profile of Postpartum Crossbred Anestrous Cows Compared with the Cyclic Cows
}

\author{
AK Mondal, S Begum, S Islam, MMI Hasan, MM Rahman and MMR Howlader* \\ Department of Physiology, Bangladesh
}

*Corresponding author: Matiar Rahman Howlader, Department of Physiology, Faculty of Veterinary, Animal and Biomedical Sciences, Sylhet-3100, Bangladesh

\section{ARTICLE INFO}

Received: 慧 April 18, 2019

Published: 幽 April 26, 2019

Citation: AK Mondal, S Begum, S Islam, MMI Hasan, MMR Howlader, et al. Assessment of Hematobiochemical Profile of Postpartum Crossbred Anestrous Cows Compared with the Cyclic Cows. Biomed J Sci \& Tech Res 17(3)-2019. BJSTR. MS.ID.003018.

Keywords: Postpartum; Anestrous; Cyclic; Crossbred; Hematobiochemical Profile

Abbreviations: RBC: Red Blood Cell; WBC: White Blood Cell; Hb: Hemoglobin; PCV: Packed Cell Volume; TEC: Total Erythrocyte Count; TLC: Total Leukocyte Count; AST: Aminotransferase; DLC: Differential Leukocyte Count; CI: Confidence Interval

\author{
ABSTRACT
}

Hemato-biochemical parameters are the key features of good physiological condition, where good physiological condition is the precursor of good production. For this reason the present study was aimed to assess the mean values of different hematological and biochemical profile of postpartum crossbred anestrous cows and determining differences among the mean values of different hematological and biochemical profile between cyclic and postpartum crossbred anestrous cows in the study areas. The study population was 30 crossbred cows. The animals were sampled purposively and divided into two groups. Group A which is the target group was suffering from post-partum anestrous of more than 90 days and group B which is the control group was cycling cows of crossbreed. Blood samples from cows with anestrous and cyclic were collected for hematological, biochemical and hormonal status analysis. T-test was performed to check the mean and standard error where confidence interval was $95 \%$. All the analysis was performed at the 0.05 significance level. The Erythrocyte Sedimentation Rate was not significantly lower and Hemoglobin percentage was significantly higher in anestrous cows than normal cycling control cows.

Packed Cell Volume percentage in anestrous group of cows was significantly lower than that of control group of cows. The Total Erythrocyte Count was significantly higher in anestrous cows than normal cycling control cows. The Total Leukocyte Count in anestrous group of cows was significantly higher than that in the control group of cows. In Differential Leukocyte Count, neutrophil in anestrous group of cows was significantly higher showing the presence of an inflammatory process and eosinophil was significantly lower than that in the control group of cows. The mean total serum protein was not significantly lower in anestrous group of cows than that of control group of cows. The mean bilirubin concentration in anestrous group of cows was significantly higher than in control group of cows. The mean Alanine aminotransferase and Aspartate Aminotransferase was significantly higher in anestrous group of cows than that of control group of cows. The mean values of progesterone, Follicle stimulating hormone and Luteinizing hormone of anestrous cows were significantly lower than in control group of cows. It is suggested that there is no specific hematological and biochemical marker for anestrous in crossbred cows rather it may be hormonal cause for anestrous.

\section{Introduction}

Reproductive performance is one of the major indicators measuring the profitability of the dairy farmers Mondol et al. [1]. Now a day's dairy farming faces several constraints such as reproductive diseases, nutritional deficiency and im -proper management in Bangladesh. Anestrous is one of the commonly occurring reproductive diseases in dairy cows affecting livestock productivity and economy Shirazet al. [2]. Anestrous is the major component of postpartum infertility and is affected by several factors: season, breed, parity, dystocia, nutrition etc Short et al. [3]. The hemato-biochemical profile may vary in normal cycling and 
anestrous animals Geneser [4]. Since hematobiochemical profile changes during various reproductive states, it is imperative to study hematological constituents during these states. A significant increase of Red Blood Cell (RBC) and White Blood Cell (WBC) occurs during estrous phase in cattle Soliman et al. [5]. Hemoglobin $(\mathrm{Hb})$ level decrease in anestrous than in cycling buffaloes and cows, respectively Dhoble et al. [6,7]. The total erythrocyte count (TEC), hemoglobin concentration (Hb) and Packed Cell volume (PCV) are decreased in anestrus and repeat breeder animals while mean corpuscular volume and total leukocyte count (TLC)are increased in these two groups Kumar et al. [8].

High incidence of repeat-breeding and anestrous are associated with the deficiencies of cholesterol Kumar et al. [8], glucose Jani et al. [9], protein, albumin and globulin Joe Arosh et al. [10]. Lower Aspartate Aminotransferase (AST) is associated with the anestrous condition of cows Arosh et al. [10]. Hemato-biochemical studies are important in diagnosis of healthy and diseased conditions of the animals. The knowledge of hematological values is useful in diagnosing various pathological and metabolic disorders, which can adversely affect the productive and reproductive performance of cows, resulting in great economic losses to dairy farmers Pyne et al. $[11,12]$. Therefore, aim of the present study was to investigate various hematological and biochemical profile and comparing the hematological and biochemical profile between cyclic and postpartum crossbred anestrous cows.

\section{Materials and Methods}

\section{Study Area}

The study was undertaken at six dairy farms in Sylhet Upazila Sadar, Sylhet, Bangladesh.

\section{Study Population}

The study population was 30 crossbred cows. The animal was sampled purposively and divided into two groups. Group A which is the target group $(n=15)$ was suffering from post-partum anestrous of more than 90 days and group B which is the control group $(n=15)$ was cycling cows of crossbred.

\section{Management of the Study Population}

Proper balanced diets were supplied in those farms. The concentrated feed was containing Moisture (Maximum) -12-13 $\%$; Crude protein (Minimum) - $21 \%$; Crude fat (Minimum) -4$4.5 \%$; Crude fiber (Maximum) -9-10\%; Total digestible nutrients (Minimum) -64 \%; Calcium (Minimum) -1.5\%; Phosphorus (Minimum) $-0.65 \%$. For fodder, straw and green grasses were used as $6 \mathrm{~kg} / 100 \mathrm{~kg}$ body weight of the cattle. Fresh and clean drinking water was provided as adlib tam. Proper vaccination schedule (For Anthrax, Black Quarter, Foot and Mouth Disease and Hemorrhagic Septicemia) and deworming (Regular basis on 3 months interval) were followed in those farms. Proper hygienic and strict sanitary measures were taken in the farm.

\section{Sample Collection}

Five (5) ml blood was collected from each cow by jugular vein puncture using ten (10) ml plastic syringe. The hematological studies were performed within two hours of the blood collection. Rest of the sample was taken in vials for collection of serum. Serum sample was kept at -200C until analyzed.

\section{Methods}

Estimations of Hemoglobin ( $\mathrm{Hb})$, Erythrocyte Sedimentation Rate (ESR), Packed Cell Volume (PCV), Total Erythrocyte Count (TEC), Total Leukocyte Count (TLC) were performed following the methods described by Lamberg et al. [13] at the physiology laboratory of Sylhet Agricultural University, Sylhet. Differential Leukocyte Count (DLC) and biochemical tests were performed by using Vitros-5600 Integrated Systems/ Vitros-250 Automated dry Biochemistry Analyzerat Popular Medical Centre Ltd., Sylhet, Bangladesh. Hormonal tests were performed at Institute of Nuclear Medicine and Allied Sciences, M. A. G. Osmani Medical College Campus, Sylhet, Bangladesh.

\section{Statistical Analysis}

T-test was performed to obtain the mean and standard error by using SPSS software where confidence interval (CI) was 95\%. All the analysis was performed at the 0.05 significance level.

\section{Results}

\section{Hematological Parameter}

Table 1: Values of ESR, PCV, Hb, TEC, TLCand DLCof target group (postpartum crossbred anestrous cows) and control group (cyclic cows).

\begin{tabular}{|c|c|c|c|c|}
\hline \multirow{2}{*}{\multicolumn{2}{|c|}{ Parameters }} & \multicolumn{2}{|c|}{ Mean \pm SE } & \multirow{2}{*}{ P-value } \\
\hline & & Target group $(\mathrm{n}=15)$ & Control group (n=15) & \\
\hline \multicolumn{2}{|c|}{ ESR (mm in 1st hour) } & $0.118 \pm 0.004$ & $0.120 \pm 0.005$ & 0.785 \\
\hline \multicolumn{2}{|c|}{ PCV (\%) } & $31.20 \pm 0.611$ & $40.07 \pm 0.784$ & 0.000 \\
\hline \multicolumn{2}{|c|}{$\mathrm{Hb}(\mathrm{gm} \%)$} & $12.466 \pm 0.336$ & $9.073 \pm 0.291$ & 0.000 \\
\hline \multicolumn{2}{|c|}{ TEC (million/ $\mu \mathrm{l})$} & $5.711 \pm 0.254$ & $4.516 \pm 0.055$ & 0.000 \\
\hline \multicolumn{2}{|c|}{ TLC (thousand/ $\mu \mathrm{l}$ ) } & $9.160 \pm 0.145$ & $6.340 \pm 0.097$ & 0.000 \\
\hline \multirow{4}{*}{ DLC } & Neutrophil (\%) & $36.93 \pm 4.560$ & $26.07 \pm 0.248$ & 0.032 \\
\hline & Lymphocyte (\%) & $59.07 \pm 4.602$ & $63.60 \pm 0.702$ & 0.346 \\
\hline & Monocyte (\%) & $2.13 \pm 0.215$ & $3.47 \pm 0.682$ & 0.080 \\
\hline & Eosinophil (\%) & $1.87 \pm 0.091$ & $6.87 \pm 0.551$ & 0.000 \\
\hline
\end{tabular}


The mean values of ESR were $0.118 \pm .004$ and $0.120 \pm 0.005$ $\mathrm{mm}$ in $1^{\text {st }}$ hour in anestrous and control group of cows, respectively (Table 1). The mean PCV in anestrous group and control group was $31.20 \pm 0.611$ and $40.07 \pm 0.784$, respectively (Table 1 ). The mean $\mathrm{Hb}(\mathrm{gm} \%)$ in anestrous group and control group of cows was $12.466 \pm 0.336$ and $9.073 \pm 0.291$, respectively (Table 1 ). The mean values of TEC of anestrous group of cows and control groups cows were $5.711 \pm 0.254$ and $4.516 \pm 0.055$ million/ $\mu$ l, respectively (Table 1). The mean values of TLC in anestrous and control group of cows was $9.160 \pm 0.145$ and $6.340 \pm 0.097$ thousand $/ \mu \mathrm{l}$ respectively (Table 1). In cows from anestrous group, neutrophils had an average value of $36.93 \pm 4.560 \%$, compared to the control group $(26.07 \pm 0.248 \%)$ showing the presence of an inflammatory process (Table 1). Lymphocytes had lower values in cows of the anestrus group $(59.07 \pm 4.602 \%)$, compared to the control group of cows $(63.60 \pm 0.702 \%)$ while eosinophil $(1.87 \pm 0.091 \%)$ and monocytes $(2.13 \pm 0.215 \%)$ have shown lower values compared to the control group $(6.87 \pm 0.551 \%$ and $3.47 \pm 0.682 \%)$ (Table1).

\section{Biochemical Parameter}

Table 2: Values of Total serum protein, Serum albumin, Serum globulin,Serum bilirubin, Alanine aminotransferase (ALT) and Aspartate Aminotransferase (AST) of target group (postpartum crossbred anestrous cows) and control group (cyclic cows)

\begin{tabular}{|c|c|c|c|}
\hline \multirow{2}{*}{ Parameters } & \multicolumn{2}{|c|}{ Mean \pm SE } & \multirow{2}{*}{ P-value } \\
\cline { 2 - 4 } & Target group $(\mathrm{n}=15)$ & Control group (n=15) & 0.195 \\
\hline Total serum protein (gm/dl) & $5.549 \pm 0.410$ & $6.194 \pm 0.255$ & 0.182 \\
\hline Serum albumin (gm/dl) & $2.470 \pm 0.221$ & $2.819 \pm 0.121$ & 0.255 \\
\hline Serum globulin (gm/dl) & $3.062 \pm 0.214$ & $3.372 \pm 0.155$ & 0.000 \\
\hline Serum bilirubin (mg/dl) & $0.636 \pm 0.0160$ & $0.323 \pm 0.020$ & 0.000 \\
\hline ALT (IU/L) & $48.67 \pm 2.806$ & $22.67 \pm 0.333$ & 0.000 \\
\hline AST (IU/L) & $73.33 \pm 3.588$ & $29.67 \pm 0.333$ & \\
\hline
\end{tabular}

The mean total serum protein in anestrous and control group of cows were $5.549 \pm 0.410$ and $6.194 \pm 0.255 \mathrm{gm} / \mathrm{dL}$, respectively (Table 2). The mean serum albumin in anestrous and control group of cows were $2.470 \pm 0.221$ and $2.819 \pm 0.121 \mathrm{gm} / \mathrm{dl}$, respectively (Table 2). The mean serum globulin in anestrous and control group of cows were $3.062 \pm 0.214$ and $3.372 \pm 0.155 \mathrm{gm} / \mathrm{dL}$, respectively (Table 2). The mean concentration of serum bilirubin in anestrous and control group of cows was $0.636 \pm 0.0160$ and $0.323 \pm 0.020 \mathrm{mg} /$ $\mathrm{dl}$, respectively (Table 2). The mean ALT in anestrous and control group of cows were $48.67 \pm 2.806$ and $22.67 \pm 0.333 \mathrm{IU} / \mathrm{L}$, respectively

\section{IU/L, respectively (Table 3).}

Table 3: Values of Progesterone, Follicle Stimulating Hormone (FSH) and Luteinizing Hormone (LH)of target group (postpartum crossbred anestrous cows) and control group (cyclic cows).

\begin{tabular}{|c|c|c|c|}
\hline \multirow{2}{*}{ Parameters } & \multicolumn{2}{|c|}{ Mean \pm SE } & \multirow{2}{*}{ P-value } \\
\cline { 2 - 4 } & Target group (n=7) & Control group (n=7) & 0.000 \\
\hline Progesterone (nM/L) & $8.188 \pm 0.169$ & $11.522 \pm 0.197$ & 0.000 \\
\hline FSH (IU/L) & $2.631 \pm 0.080$ & $10.771 \pm 0.697$ & 0.000 \\
\hline LH (IU/L) & $2.577 \pm 0.062$ & $16.892 \pm 0.656$ & \multirow{2}{*}{0} \\
\hline
\end{tabular}

\section{Discussion}

The mean difference of ESR between anestrous and control group is not significant (Table 1). The ESR is generally higher in anestrous cows than control cows.The ESR values of the present study are lower than the result of Pariza et al. [14] whereas Pariza et al. [14] reported that the mean values of ESR were significantly higher in anestrous group compared to the control group of cows. The ESR is increased in inflammation, pregnancy, anemia, autoimmune disorders (such as rheumatoid arthritis and lupus), infections, some kidney diseases and some cancers (such as lymphoma and multiple myeloma). The ESR is decreased in polycythemia, hyperviscosity, sickle cell anemia, leukemia, low
(Table 2). The mean AST in anestrous and control group of cows were $73.33 \pm 3.588$ and $29.67 \pm 0.333 \mathrm{IU} / \mathrm{L}$, respectively (Table 2).

\section{Hormonal Parameter}

The mean concentration of progesterone level in anestrous group was $8.188 \pm 0.169$ and in control group was $11.522 \pm 0.197$ $\mathrm{nM} / \mathrm{L}$ (Table 3). The mean concentration of FSH in anestrous and control group of cows was $2.631 \pm 0.080$ and $10.771 \pm 0.697 \mathrm{IU} / \mathrm{L}$, respectively (Table 3). The mean concentration of LH in anestrous and control group of cows was $2.577 \pm 0.062$ and $16.892 \pm 0.656$ 
$[1,18,14,17]$. The mean values of TEC of anestrous group of cows and control groups cows were $5.711 \pm 0.254$ and $4.516 \pm 0.055$ million/ $\mu$ l, respectively (Table 1 ). The difference in TEC between anestrous and control groups of cows is highly significant (Table 1).This is not similar with the finding of the study done by Pariza et al. [1,1418]. The mean values of TLC in anestrous and control group of cows was $9.160 \pm 0.145$ and $6.340 \pm 0.097$ thousand/ $\mu \mathrm{l}$ respectively (Table 1). The TLC in anestrous group of cows is significantly higher than that in the control group of cows (Table 1). The finding of TLC of the present study is similar with the result of Pariza et al. $[14,17,18]$. Possibly bacterial infection was present in the anestrous cows.In cows from anestrous group, neutrophils had an average value of $36.93 \pm 4.560 \%$, compared to the control group $(26.07 \pm 0.248 \%)$ showing the presence of an inflammatory process (Table 1). Lymphocytes had lower values in cows of the anestrus group $(59.07 \pm 4.602 \%)$, compared to the control group of cows $(63.60 \pm 0.702 \%)$ while eosinophil $(1.87 \pm 0.091 \%)$ and monocytes $(2.13 \pm 0.215 \%)$ have shown lower values compared to the control group $(6.87 \pm 0.551 \%$ and $3.47 \pm 0.682 \%)$ (Table 1$)$.

The difference in eosinophil between anestrous and control groups of cows is highly significant whereas the difference in neutrophils, lymphocytes and monocytes between anestrous and control groups of cows is not significant (Table 1). This is not similar with the finding of the study done by Ruginosu et al. [17]. The mean total serum protein is not significantly lower in anestrous group of cows than that of control group of cows (Table 2). This is not similar with the finding of the study done by Pariza et al. [14] where it reported that the mean total serum proteinwas significantly lower in anestrous group of cows than that of control group of cows. The mean serum albumin is not significantly lower in anestrous group of cows than that of control group of cows (Table 2). This is similar with the finding of the study done by Mondal and Paul, 2012 but not similar with the finding of the study done by Amle et al. [19]. The mean serum globulin is not significantly lower in anestrous group of cows than that of control group of cows (Table 2). This is not similar with the finding of the study done by Mondal et al. $[17,19]$. The mean bilirubin concentration in anestrous group of cows is significantly higher than in control group of cows (Table 2).

This is similar with the finding of the study done by Pariza et al. [14] where it reported that the mean bilirubin concentration in anestrous group of cows was significantly higher than in control group of cows. The mean ALTis significantly higher in anestrous group of cows than that of control group of cows (Table 2). Serum level of ALT is increased in case of parasitic infection and liver damage. The mean AST is significantly higher in anestrous group of cows than that of control group of cows (Table 2). According to Keele et al. [20], serum levels of AST are significantly high under disease and morbid conditions involving injuries to large numbers of metabolically active cells. The difference of concentration of progesterone between anestrous and control group is significant (Table 3). This is not similar with the finding of the study done by Pariza et al. [14]. The mean FSH concentration in anestrous group of cows is significantly lower than in control group of cows (Table 3). The mean LH concentration in anestrous group of cows is significantly lower than in control group of cows (Table 3). The
Values of ALT and AST are significantly higher in anestrous cows than in cyclic cows. Higher level of AST indicates liver damage and proteinases substances are produced from liver. The hormones are proteinases substances. That's why higher level of AST resulting liver damage and hampering the hormonal balance. As a result, FSH, LH and progesterone level are significantly lower in anestrous cows than control group of cyclic cows and finally leads to anestrous condition.

\section{Conclusion}

This research work is carried out to investigate the hematological and biochemical profiles of postpartum crossbred anestrous cows and cyclic cows. The study results show the significant variation in some of the hemato-biochemical parameters [21]. The ESR values are non- significantly lower in anestrous cows; however, the $\mathrm{Hb}$ values are significantly higher and PCV values are significantly lower in anestrous cows. The difference in TEC between anestrous and control groups of cows is highly significant. The TLC is significantly higher in anestrus cows than in control cows. Possibly bacterial infection is present in the anestrous cows. Indeed, chronic microbial infection may cause endometritis that might be responsible for anestrous. In this study, eosinophil count is significantly lower in anestrous cows than in cyclic cows. In cows from anestrous group, neutrophil is showing the presence of an inflammatory process. Similarly, the values of lymphocytes and monocytes do not differ in between the anestrous and cyclic group of cows. Total serum protein is low in all anestrous cows than control cows. In the present investigation, total serum bilirubin is higher in anestrous cows than control cows whereas AST and ALT is significantly higher in anestrous group of cows than that of control group of cows. There is significant difference of progesterone, FSH and LH level in anestrous and cyclic cows. The study cows are reared under well balanced diet, proper vaccination as well as proper sanitation. So it can be concludes that there is no specific hematological and biochemical marker for anestrous in crossbred cows and the anestrous condition might be due to the hormonal cause.

\section{Acknowledgement}

I would like to express my deepest gratitude to all the owners of the farms and Ministry of Science and Technology of the Government of the People's Republic of Bangladesh to provide the financial support to successfully complete the research work.

\section{References}

1. Mondal MK, Paul SK (2012) Hematobiochemical Profile in Repeat Breeding Crossbred Cows (2012). Explor Anim Med Res 2(1): 60-65.

2. Shiraz khan, A Thangavel, S Selvasubramaniyan (2010) Blood Biochemical profile in repeat Breeding cows. Tamilnadu J Veterinary \& Animal Sciences 6(2): 75-80.

3. Short RE, Bellows RA, Staigmiller RB, Berardinelli JG, Custer EE (1990) Physiological mechanisms controlling anestrus and infertility in postpartum beef cattle. Journal of Animal Science 68(3): 799-816.

4. Geneser F (1986)Textbook of Histology, (1 ${ }^{\text {st }}$ Edn). Munksgaard, Copenhagen, Denmark.

5. Soliman MK, Zaki K (1963) Blood picture of Friesian cows during oestrous cycle and pregnancy. J Arab Vet Med Assoc 4: 343-354. 
6. Dhoble RL, Gupta SK (1981) Total plasma protein and haemoglobin status during estrous cycle and anestrus in postpartum buffaloes. Indian Vet J 58: 544-547.

7. Nadiu KV, Rao AR (1982) A study on the etiology of anestrus in crossbred cows. Indian Vet J 59: 780-781.

8. Kumar S, Sharma MC (1991) Level of haemoglobin and certain serum biochemical constituents in rural cows during fertile and non-fertile estrus. Indian Vet J 68: 361-364.

9. Jani RG, Prajapati BR, Dave MR (1995) Hematological and biochemical changes in normal fertile and infertile Surtibuffaloe heifers, Indian. J Anim Reprod 5: 14-22.

10. Joe Arosh A, Kathiresan D, Devanathan TG, Rajasundaram RC, Rajasekaran J (1998) Blood biochemical profile in normal cyclical and anoestrous cows. Indian J Anim Sci 68: 1154-1156.

11. Dutta JC, Baruah RN, Dutta L, Talukar SC (1988) Blood biochemical studies in anoestrus and normal cyclic cattle. Indian Vet J 65: 239-241.

12. Pyne AK, Maira DN (1981) Physiological studies on blood of lactating Hariana and Sahiwal cattle. Indian Vet J 58: 526-528.

13. Lamberg SL, Rothstein R (1977) Laboratory manual of hematology and urine analysis $\left(1^{\text {st }} \mathrm{edn}\right)$.

14. Pariza KF, Alam J, Islam MR, Hossain MM, Awal MA (2013) Investigation of hematological and biochemical profiles of anestrous zebu cows. Bangladesh Journal of Veterinary Medicine 11(1): 57-60.

\section{ISSN: 2574-1241}

DOI: 10.26717/BJSTR.2019.17.003018

Matiar Rahman Howlader. Biomed J Sci \& Tech Res

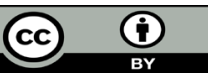

This work is licensed under Creative Commons Attribution 4.0 License

Submission Link: https://biomedres.us/submit-manuscript.php
15. Baki MA, Rahman MM (1981) Study on some Hematological values of Diestrus and Anestrous cows of Pabna Breed. Bangladesh Veterinary Journal 21(1-2): 15-18.

16. Samad MA, Rahman A, Ali KM (1978) A note on certain blood chemical and hematological values of repeat breeding heifers caused by glandular vulvo vaginitis. Indian Journal of Animal Science 69: 5-9.

17. Ruginosu E, Creanga St, Mariana S, Alina A, Solcan G (2010) The Hematologic Profile of Cattle with Reproductive Diseases. Cercetari Agronomice in Moldova 18(2): 142.

18. Ahmad I, Gohar A, Ahmad N, Ahmad M (2003) Haematological profile in cyclic, non-cyclic and endometritic cross bred cattle. Int J Agri Biol 5(3): 332-334.

19. Amle M, Patodkar V, Shelar R, Birade H (2014) Serum Biochemical Levels of Repeat Breeder Cross Bred Cows under Rural Condition of Satara District of Maharashtra. International Journal of Advanced Veterinary Science and Technology 3(1): 109-113.

20. Keele CA, Neil E (1971) Samson Wrights Applied Physiology. (12 ${ }^{\text {th }}$ Edn.). ELBS and OUB, London, pp. 576.

21. Kumar S, Sharma MC (1993) Hematological changes during fertile and nonfertile estrous in rural buffaloes. Buffaloe J 9: 69 -73.

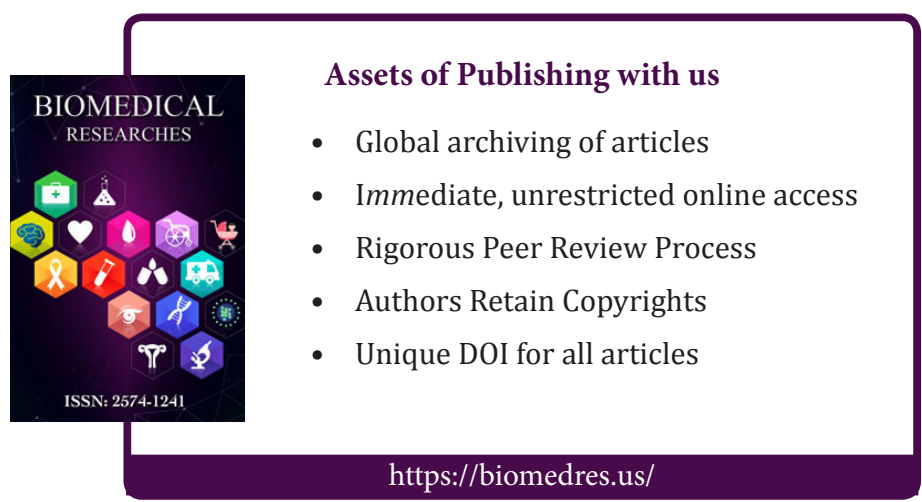

